Glass Ceramic

Formulation Data

Package

Fuel Cycle Research \& Development

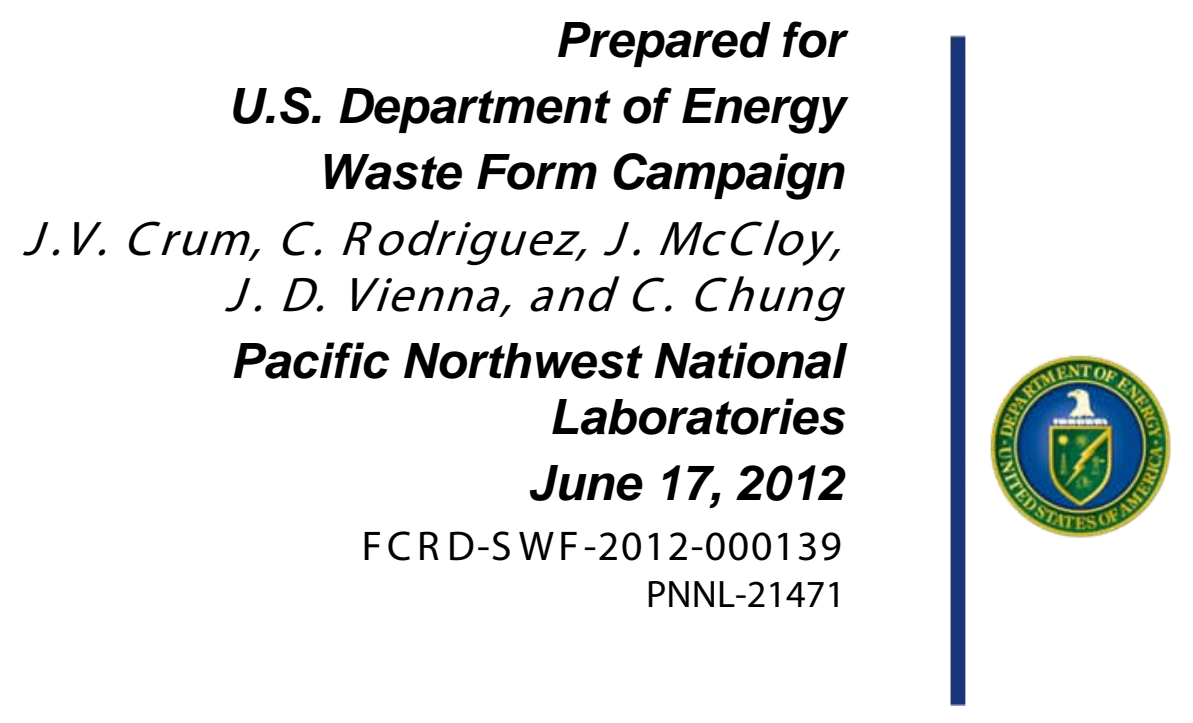




\section{DISCLAIMER}

This information was prepared as an account of work sponsored by an agency of the U.S. Government. Neither the U.S. Government nor any agency thereof, nor any of their employees, makes any warranty, expressed or implied, or assumes any legal liability or responsibility for the accuracy, completeness, or usefulness, of any information, apparatus, product, or process disclosed, or represents that its use would not infringe privately owned rights. References herein to any specific commercial product, process, or service by trade name, trade mark, manufacturer, or otherwise, does not necessarily constitute or imply its endorsement, recommendation, or favoring by the U.S. Government or any agency thereof. The views and opinions of authors expressed herein do not necessarily state or reflect those of the U.S. Government or any agency thereof. 


\section{CONTENTS}

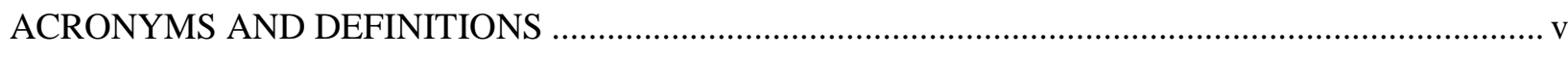

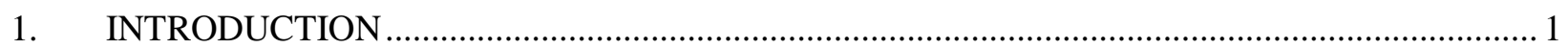

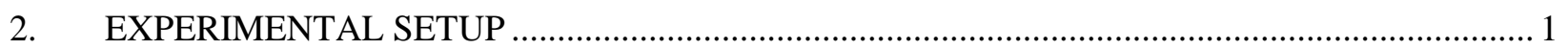

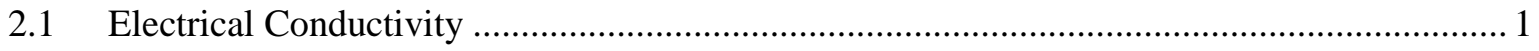

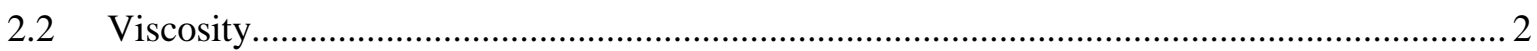

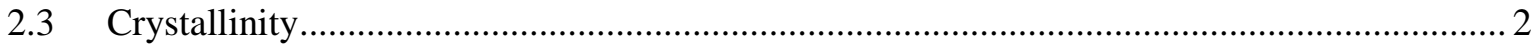

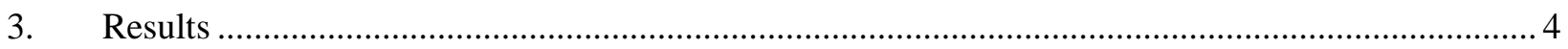

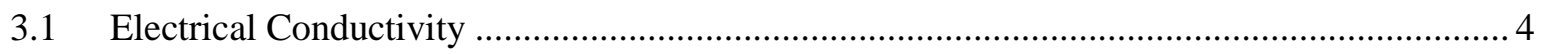

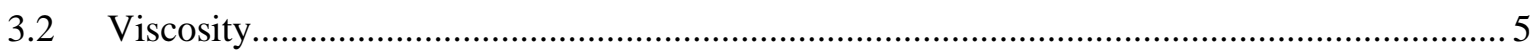

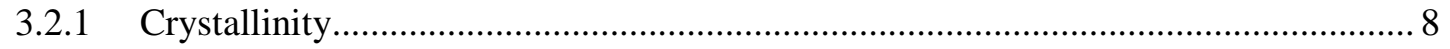

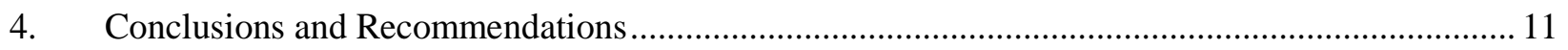

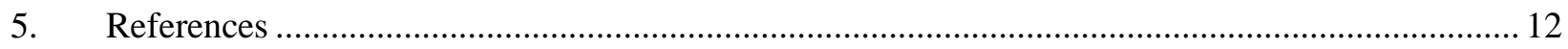

\section{FIGURES}

Figure 1. Electrical conductivity measurement temperature schedule (Crum and McCloy 2012)............. 2

Figure 2. Slow cooling temperature schedules from $0.25 \times$ to $4 \times$ that of 2 -foot diameter canister centerline temperature profile.

Figure 3. Arrhenius electrical conductivity relationship of glass ceramics and DWPF standard glass.

Figure 4. Arrhenius viscosity relationship of GC-Mo-Li-6.25 glass ceramic. The blue shaded region denotes the temperature range where the viscosity is significantly impacted by crystallization.

Figure 5. Shear stress versus shear rate of GC-Mo-Li-6.25 glass ceramic as a function of temperature.

Figure 6. X-ray powder diffraction patterns of GC-Mo-Li-6.25 slow cooled at rates of $0.25 \times$, $0.5 \times, 0.75 \times, 1 \times, 2 \times$, and $4 \times$ relative to centerline cooling rate for 2 ' diameter canister ( $\mathrm{K}_{\alpha 2}$ fit and removed, amorphous background retained).

Figure 7. Backscattered electron images (500×) of GC-Mo-Li-6.25 slow cooled at various rates $(0.25 \times, 0.5 \times, 0.75 \times, 1 \times, 2 \times$, and $4 \times)$

\section{TABLES}

Table 1. Slow cooling (SC) temperature schedules ( $4 \times$ to $0.25 \times$ ) based on $1300^{\circ} \mathrm{C}$ melting temperature.

Table 2. Measured electrical conductivity $(\sigma$ in $\mathrm{S} / \mathrm{m})$ as a function of temperature and fitted Arrhenius coefficients. 
Table 3. Quantitative XRD analysis results for GC-Mo-Li-6.25 glass ceramic as a function of slow cooling rate (relative to centerline cooling rate of 2' diameter canister). 10

Table 4. Image analysis (SEM) and measured crystallinity (XRD) as a function of slow cool rate (values in volume \%)

Table 5. Summary data table for GC-Mo-Li-6.25 glass ceramic. 


\title{
ACRONYMS AND DEFINITIONS
}

\author{
$\sigma \quad$ electrical conductivity \\ $\eta \quad$ viscosity \\ A slope of Arrhenius equation \\ B intercept of Arrhenius equation \\ ASTM ASTM International (formerly American Society for Testing and Materials) \\ BSE backscatter electron (imaging detector) \\ CCIM cold crucible induction melter \\ DWPF Defense Waste Processing Facility \\ INL Idaho National Laboratory \\ PNNL Pacific Northwest National Laboratory \\ SC slow cool \\ SEM scanning electron microscope \\ SRM standard reference material \\ T temperature \\ $T_{\mathrm{M}} \quad$ melting temperature \\ XRD X-ray powder diffraction
}





\section{INTRODUCTION}

A glass ceramic waste form is being developed at Pacific Northwest National Laboratory (PNNL) for treatment of secondary waste streams generated by aqueous reprocessing of commercial used nuclear fuel (Crum et al. 2011; Crum et al. 2012b; Crum et al. 2010; Ryan et al. 2009). The waste stream contains a mixture of transition metals, alkali, alkaline earths, and lanthanides, several of which exceed the solubility limits of a single-phase borosilicate glass (Crum et al. 2009; Caurant et al. 2007). A multi-phase glass ceramic waste form allows for the incorporation of the insoluble fraction of the waste by designed crystallization into durable heat tolerant phases.

The glass ceramic formulation and processing targets the formation of the following three stable crystalline phases: 1$)$ powellite $\left(X \mathrm{MoO}_{4}\right)$ where $X$ can be (Ca, Sr, Ba, and/or Ln), 2) oxyapatite $\left(Y_{x}, Z_{(10-}\right.$ ${ }_{x)} \mathrm{Si}_{6} \mathrm{O}_{26}$ where $Y$ is alkaline earth, $Z$ is $\mathrm{Ln}$, and 3) lanthanide borosilicate $\left(\mathrm{Ln}_{5} \mathrm{BSi}_{2} \mathrm{O}_{13}\right)$. These three phases incorporate the waste components that are above the solubility limit of a single-phase borosilicate glass.

The glass ceramic is designed to be a single-phase melt, just like a borosilicate glass, and then crystallize the targeted crystalline phases upon slow cooling. The slow cooling schedule is based on the centerline cooling profile of a 2-foot diameter canister such as the Hanford high-level waste canister. Up to this point, crucible testing has been used for glass ceramic development with a cold crucible induction melter (CCIM) targeted as the ultimate processing technology for the waste form. Idaho National Laboratory (INL) will conduct a scaled CCIM test in FY2012 with a glass ceramic to demonstrate the processing behavior.

This data package documents the laboratory studies of the glass ceramic composition to support the CCIM test. Melt viscosity, electrical conductivity, and crystallization behavior upon cooling were measured to identify a processing window (temperature range) for melter operation and cooling profiles necessary to crystallize the targeted phases in the waste form.

A small set of glass ceramic compositions were selected for characterization of processing properties after which a single composition was selected for CCIM testing. A melter feed was selected based on prior laboratory scale melter testing of the baseline borosilicate glass with the same waste stream by (Riley et al. 2009). Both melter feed additives and waste loading were changed to the current glass ceramic formulation while the waste simulant remained unchanged.

\section{EXPERIMENTAL SETUP}

\subsection{Electrical Conductivity}

Impedance spectroscopy was performed on four glass compositions over a cooling temperature range of $1350^{\circ} \mathrm{C}$ to $750^{\circ} \mathrm{C}$ according to the temperature schedule plotted in Figure 1 (Crum and McCloy 2012). Duplicate impedance measurements were performed at each temperature. The impedance analyzer was calibrated "as a system" with $0.1 \mathrm{M}$ and $1 \mathrm{M} \mathrm{KCl}$ reference solutions at room temperature to determine the cell constant. In addition, a DWPF standard glass was measured to confirm the calibration results (Crum et al. 2012a). 


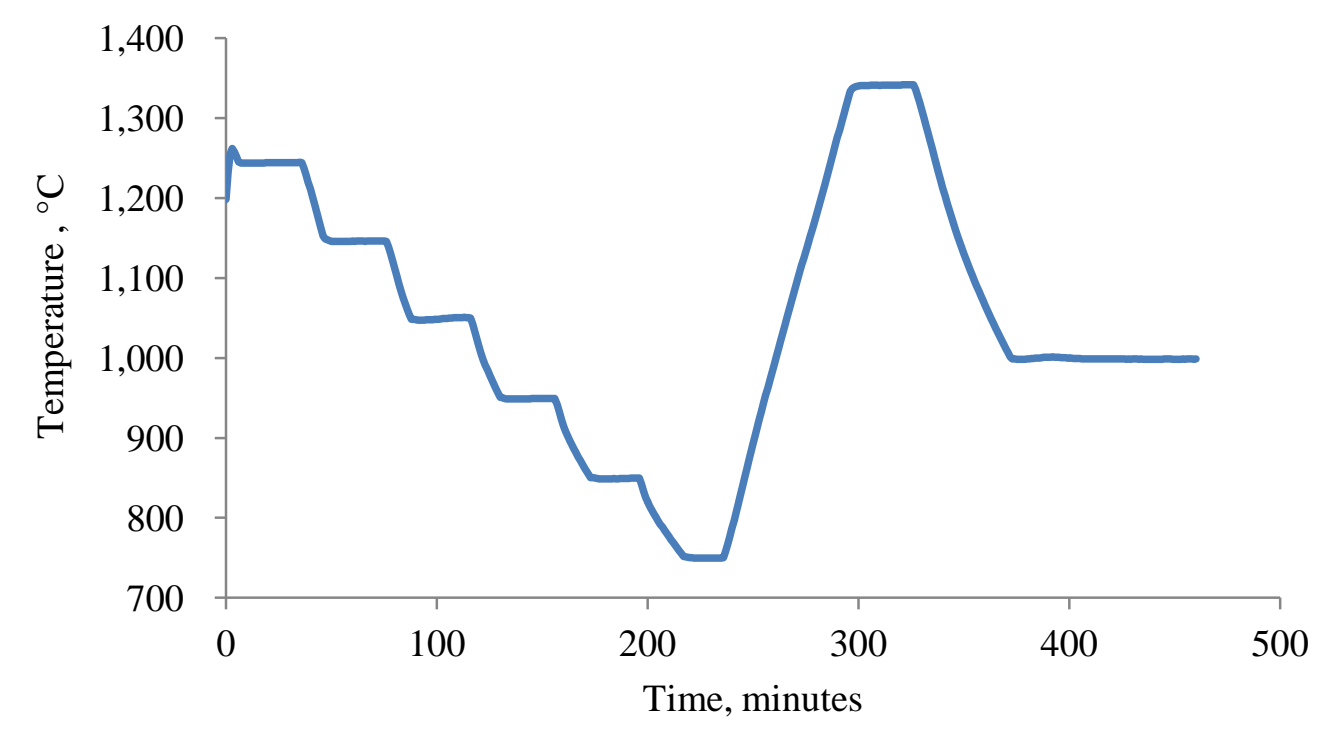

Figure 1. Electrical conductivity measurement temperature schedule (Crum and McCloy 2012).

\subsection{Viscosity}

Melt viscosity was measured according to ASTM C 965 Method A where the spindle is rotated and the crucible is fixed (ASTM-C-965-94 1994). The viscometer was calibrated with the DWPF standard glass (Crum et al. 2012a). The viscometer is most accurate for viscosities between 2 and $200 \mathrm{~Pa} \cdot \mathrm{s}$. Viscosities measured below $2 \mathrm{~Pa}$. $\mathrm{s}$ were assumed to be less accurately measured because the torque generated by the melt is below linear response range of the viscometer. Viscosities measured above $200 \mathrm{~Pa} \cdot \mathrm{s}$, on the other hand, were assumed to be less accurate because of edge effects due to crucible size. However, the data outside the 2 to $200 \mathrm{~Pa}$-s range are included in the data package because they qualitatively describe the change in behavior of the glass ceramic upon cooling and re-heating.

\subsection{Crystallinity}

Crystallization behavior of the glass ceramic was measured for a series of cooling rates, given Table 1 and graphically in Figure 2, based on the centerline cooling temperature profile of a 2-foot diameter canister. The cooling curves begin at the melting temperature $\left(T_{\mathrm{M}}\right)=1300^{\circ} \mathrm{C}$ followed by a series of seven segments with gradually slowing cooling rates down to $400^{\circ} \mathrm{C}$. Controlled cooling stopped at $400^{\circ} \mathrm{C}$ because it is $\sim 200^{\circ} \mathrm{C}$ below the glass transition temperature of the final glass phase. The cooling rates ranged from $0.25 \times$ to $4 \times$ of the typical centerline cooling temperature profile. 
Table 1. Slow cooling (SC) temperature schedules ( $4 \times$ to $0.25 \times)$ based on $1300^{\circ} \mathrm{C}$ melting temperature.

\begin{tabular}{|c|c|c|c|c|c|c|}
\hline Temperature, ${ }^{\circ} \mathrm{C}$ & $4 \times \mathrm{SC}$ & $2 \times \mathrm{SC}$ & $1 \times \mathrm{SC}$ & $0.75 \times \mathrm{SC}$ & $0.5 \times \mathrm{SC}$ & $0.25 \times \mathrm{SC}$ \\
\cline { 2 - 7 } & $\min$ & $\min$ & $\min$ & $\min$ & $\min$ & $\min$ \\
\hline 1300 & 0 & 0 & 0 & 0 & 0 & 0 \\
\hline 1150 & 0.6 & 1.3 & 2.5 & 3.3 & 5.0 & 10.0 \\
\hline 1050 & 3.6 & 7.1 & 14.3 & 19.0 & 28.6 & 57.1 \\
\hline 950 & 26.8 & 53.6 & 107.1 & 142.9 & 214.3 & 428.6 \\
\hline 886 & 56.5 & 112.9 & 225.9 & 301.2 & 451.8 & 903.5 \\
\hline 845 & 87.9 & 175.7 & 351.4 & 468.6 & 702.9 & 1405.7 \\
\hline 626 & 273.8 & 547.5 & 1095.0 & 1460.0 & 2190.0 & 4380.0 \\
\hline 400 & 484.3 & 968.6 & 1937.1 & 2582.9 & 3874.3 & 7748.6 \\
\hline Total, min & 933.3 & 1866.7 & 3733.4 & 4977.8 & 7466.8 & 14933.5 \\
\hline Total, hr & 15.6 & 31.1 & 62.2 & 83.0 & 124.4 & 248.9 \\
\hline Total, days & 0.6 & 1.3 & 2.6 & 3.5 & 5.2 & 10.4 \\
\hline
\end{tabular}

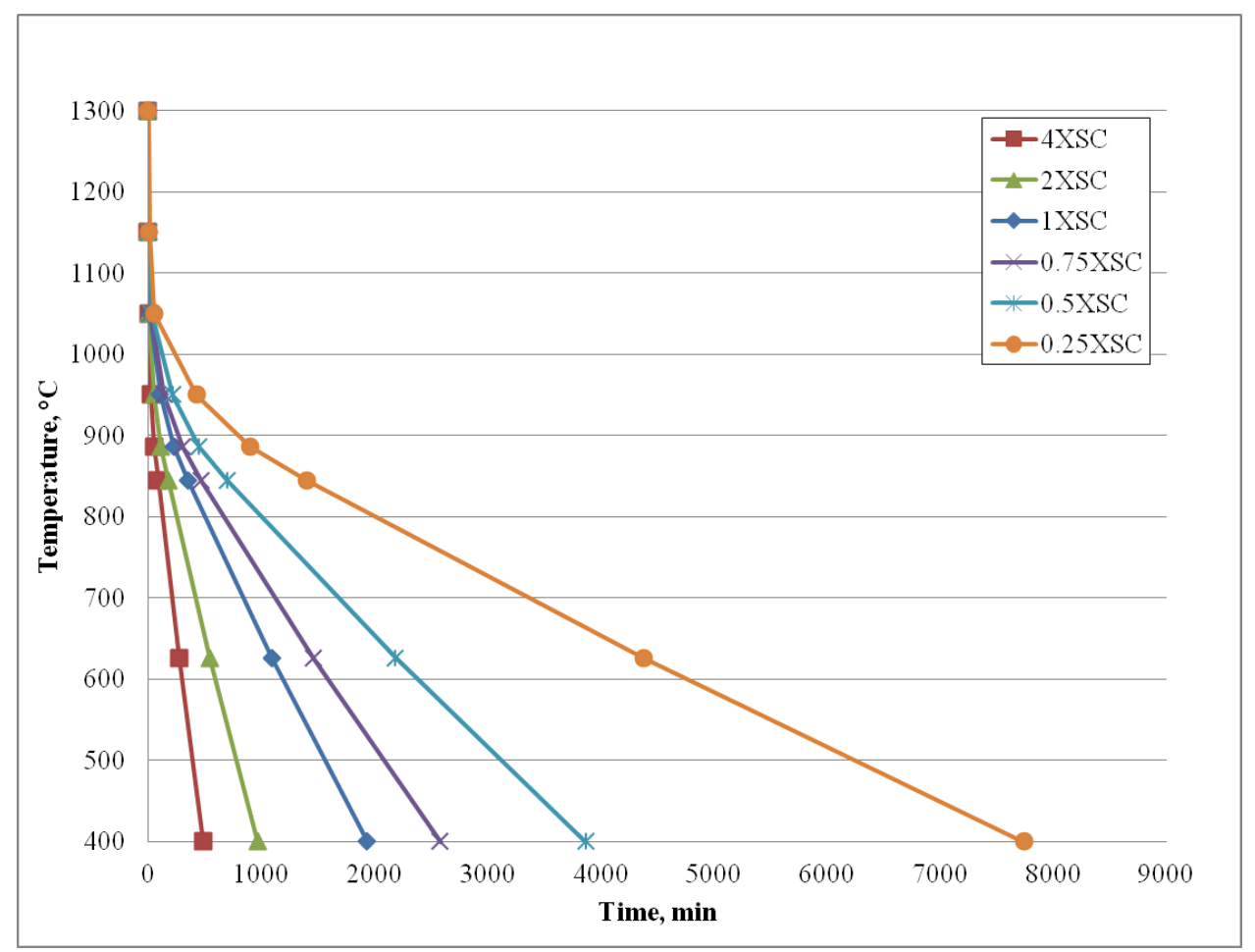

Figure 2. Slow cooling temperature schedules from $0.25 \times$ to $4 \times$ that of 2 -foot diameter canister centerline temperature profile.

The crystal types and concentrations were determined by X-ray powder diffraction (XRD). The samples were ground into a fine powder and doped with a known concentration of rutile (SRM-674b 2007). The XRD patterns were collected on Bruker D8 Advance system equipped with a Cu-target over a scan range of $5-75^{\circ} 2 \theta$ using a step size of $0.015^{\circ} 2 \theta$ and a 4 second hold time per step.

The scans were analyzed with TOPAS version 4.2 whole pattern fitting software according to the fundamental parameters approach (Cheary et al. 2004). Structure patterns were selected from the 
Inorganic Crystal Structure Database with unit cell dimensions refined in the fitting process of each pattern. The amorphous content of each sample (remainder after crystalline phases quantified) was calculated by the software based on concentration of the known internal standard.

Scanning electron microscopy (SEM) was performed to examine morphology of the slow cooled samples with a JEOL JSM-7001F microscope. The SEM was also coupled with an Apollo XL Si drift detector energy dispersive spectrometer to perform elemental analysis. Image analysis was performed to determine the volume \% of each phase with Scandium software. Phases were selected by grey scale thresholding and the software calculated the area fraction of each phase; area fractions were extrapolated into volume fractions.

\section{Results}

\subsection{Electrical Conductivity}

Electrical conductivity was the first property measured on the series of glass ceramics, with results given in Table 2. The electrical conductivity data fits the Arrhenius relationship quite well as seen in Figure 3

$$
\ln (\sigma)=B \times 1 / T+A
$$

where $\sigma$ is the electrical conductivity in $\mathrm{S} / \mathrm{m}, B$ is the slope, $T$ is temperature in $\mathrm{K}$, and $A$ is the intercept.

Four compositions were measured, of which the first three had electrical conductivities below the typical operating window of the INL CCIM. Electrical conductivity of a melt is dominated by the amount of alkali in the melt, more so the light alkali $\left(\mathrm{Li}_{2} \mathrm{O}, \mathrm{Na}_{2} \mathrm{O}\right.$, and $\left.\mathrm{K}_{2} \mathrm{O}\right)$ and less so the heavy alkali $\left(\mathrm{Rb}_{2} \mathrm{O}\right.$ and $\mathrm{Cs}_{2} \mathrm{O}$ ) (Hrma and Piepel 1994b, a). The originally formulated glass ceramics have only a small amount of $\mathrm{Na}_{2} \mathrm{O}, \mathrm{Rb}_{2} \mathrm{O}$, and $\mathrm{Cs}_{2} \mathrm{O}$ and no $\mathrm{Li}_{2} \mathrm{O}$ or $\mathrm{K}_{2} \mathrm{O}$. For this reason, a new glass ceramic was formulated (GCMo-Li-6.25) to raise the electrical conductivity by adding $\mathrm{Li}_{2} \mathrm{O}$ at the expense of other additives. The electrical conductivity determined for GC-Mo-Li-6.25 is adequate for processing in the CCIM at temperatures above $1150^{\circ} \mathrm{C}$. There is a small shift in the electrical conductivity between the temperatures of $1000^{\circ} \mathrm{C}$ and $1050^{\circ} \mathrm{C}$ that can possibly be attributed to measurement uncertainty or it may be related to a physical change in the samples, such as crystallization.

Table 2. Measured electrical conductivity ( $\sigma$ in $\mathrm{S} / \mathrm{m}$ ) as a function of temperature and fitted Arrhenius coefficients.

\begin{tabular}{|c|c|c|c|c|c|c|c|c|c|c|}
\hline$T\left({ }^{\circ} \mathrm{C}\right):$ & 750 & 850 & 950 & 1000 & 1045 & 1144 & 1242 & 1340 & \multirow{2}{*}{\multicolumn{2}{|c|}{ Arrhenius Fit }} \\
\hline$T(\mathrm{~K}):$ & 1023 & 1123 & 1223 & 1273 & 1318 & 1417 & 1515 & 1613 & & \\
\hline Sample & \multicolumn{8}{|c|}{ Electrical Conductivity ( $\sigma$ in $S / m$ ) } & $\begin{array}{c}\text { B } \\
\text { (slope) }\end{array}$ & $\begin{array}{c}\mathrm{A} \\
\text { (intercept) }\end{array}$ \\
\hline GC-Mo-5.86 & 0.06 & 0.16 & 0.45 & 0.65 & 0.78 & 1.56 & NA & NA & $-12,072$ & 8.984 \\
\hline GC-Mo-6.25 & 0.04 & 0.12 & 0.30 & 0.46 & 0.69 & 1.49 & 3.22 & 5.98 & $-14,012$ & 10.345 \\
\hline GC-Mo-6.94 & 0.03 & 0.08 & 0.20 & 0.39 & 0.49 & 1.51 & 3.44 & 6.88 & $-15,495$ & 11.324 \\
\hline GC-Mo-Li-6.25 & 0.35 & 0.94 & 1.95 & 2.32 & 3.24 & 6.44 & 11.43 & 18.50 & $-10,959$ & 9.614 \\
\hline $\begin{array}{l}\text { DWPF Startup } \\
\text { Frit }^{1}\end{array}$ & 2.51 & 6.66 & 13.20 & 17.43 & 21.13 & 31.72 & 36.96 & 37.36 & $-7,741$ & 8.763 \\
\hline
\end{tabular}

\footnotetext{
${ }^{1}$ Standard glass (Crum et al. 2012a).
} 


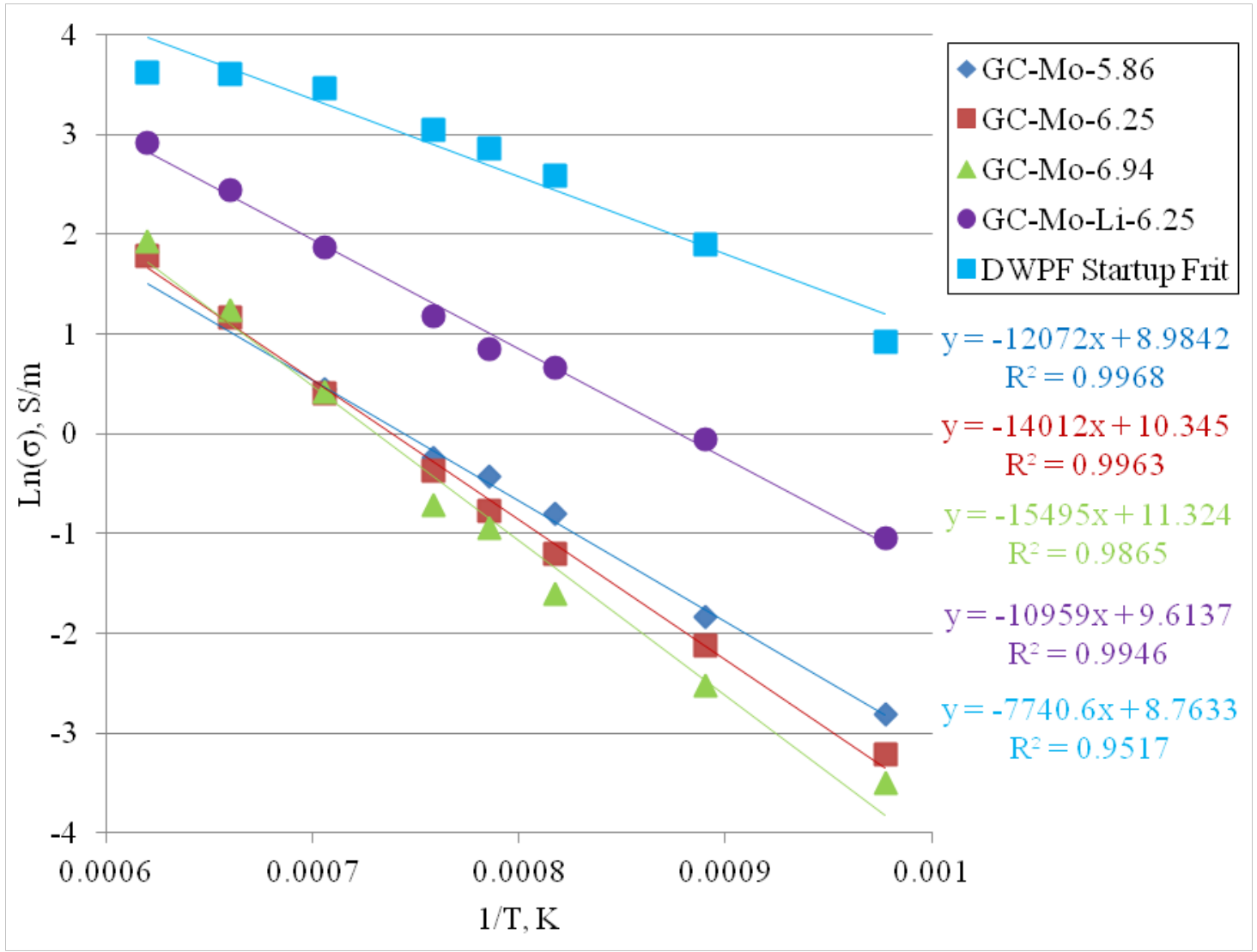

Figure 3. Arrhenius electrical conductivity relationship of glass ceramics and DWPF standard glass.

\subsection{Viscosity}

Viscosity of GC-Mo-Li-6.25 was measured as a function of temperature, upon cooling from $\sim 1350^{\circ} \mathrm{C}$ and upon reheating from a low temperature overnight hold at $850^{\circ} \mathrm{C}$, to see the impact of crystallization on melt viscosity behavior. Figure 4 shows viscosity plotted as $\ln (\eta)$ versus $1 / T$ for cooling and heating. The plot clearly shows viscosity has an Arrhenius relationship until crystallinity impacts behavior $\leq$ $1100^{\circ} \mathrm{C}(1 / T=0.00073 \mathrm{~K})$. The viscosity behavior is very similar upon heating and cooling, indicating that crystal(s) precipitation and melting happens at a similar temperature and in a short time span relative to the measurement.

These data were also plotted as shear stress versus shear rate in Figure 5 to show changes in behavior of the partially crystallized melt versus rate of flow and temperature. The yield stress is fairly constant (30 to $50 \mathrm{~Pa}$ ) above $\sim 1125^{\circ} \mathrm{C}$; however, at lower temperatures, the yield stress (intercept) increases from 50 $\mathrm{Pa}$ to $274 \mathrm{~Pa}$ as temperature decreases. Also, the plastic viscosity (slope) dramatically changes (14 $\mathrm{Pa}$ to $1400 \mathrm{~Pa}$ ) as a function of temperature between $1075^{\circ} \mathrm{C}-1125^{\circ} \mathrm{C}$. 


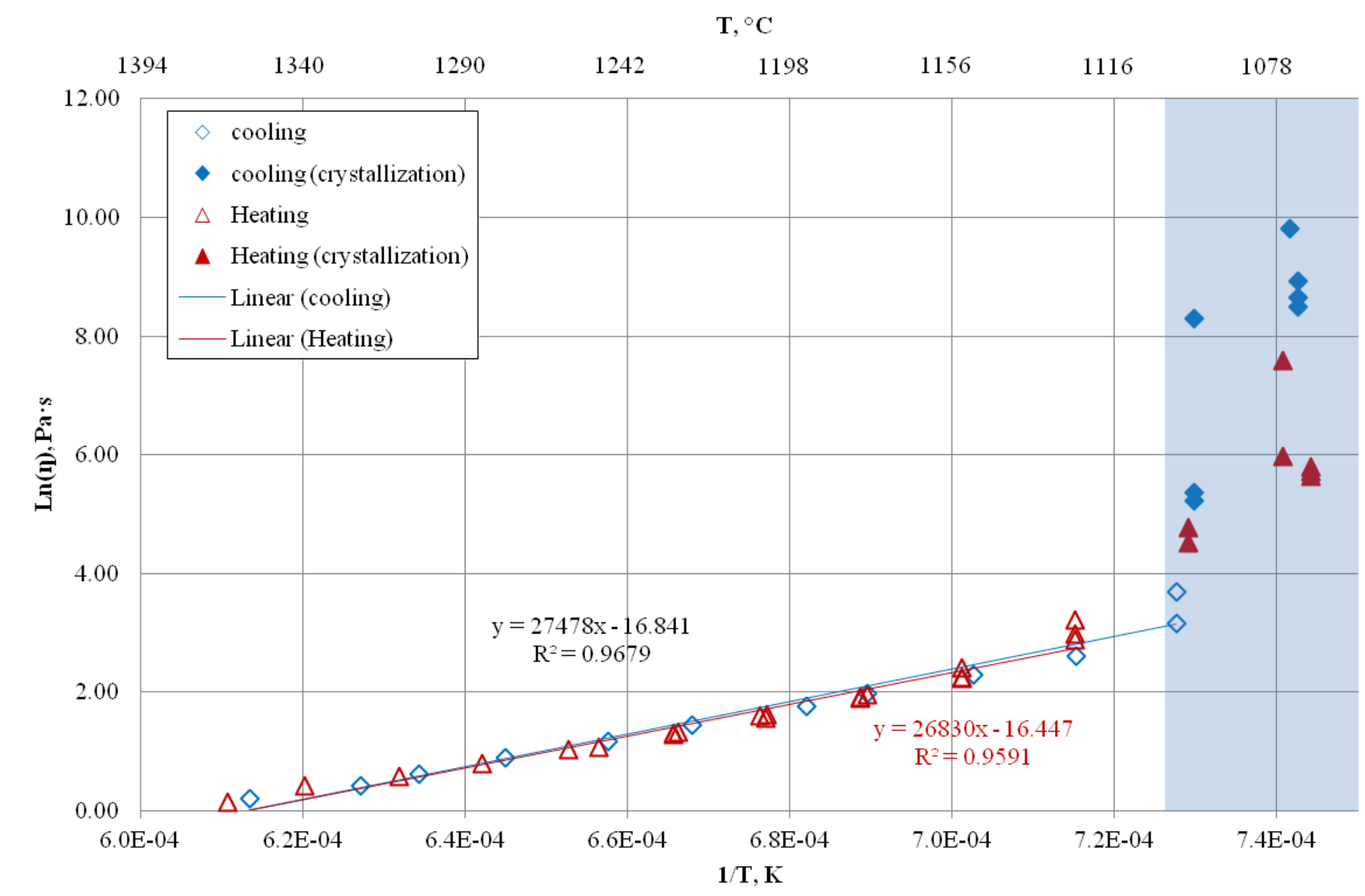

Figure 4. Arrhenius viscosity relationship of GC-Mo-Li-6.25 glass ceramic. The blue shaded region denotes the temperature range where the viscosity is significantly impacted by crystallization. 


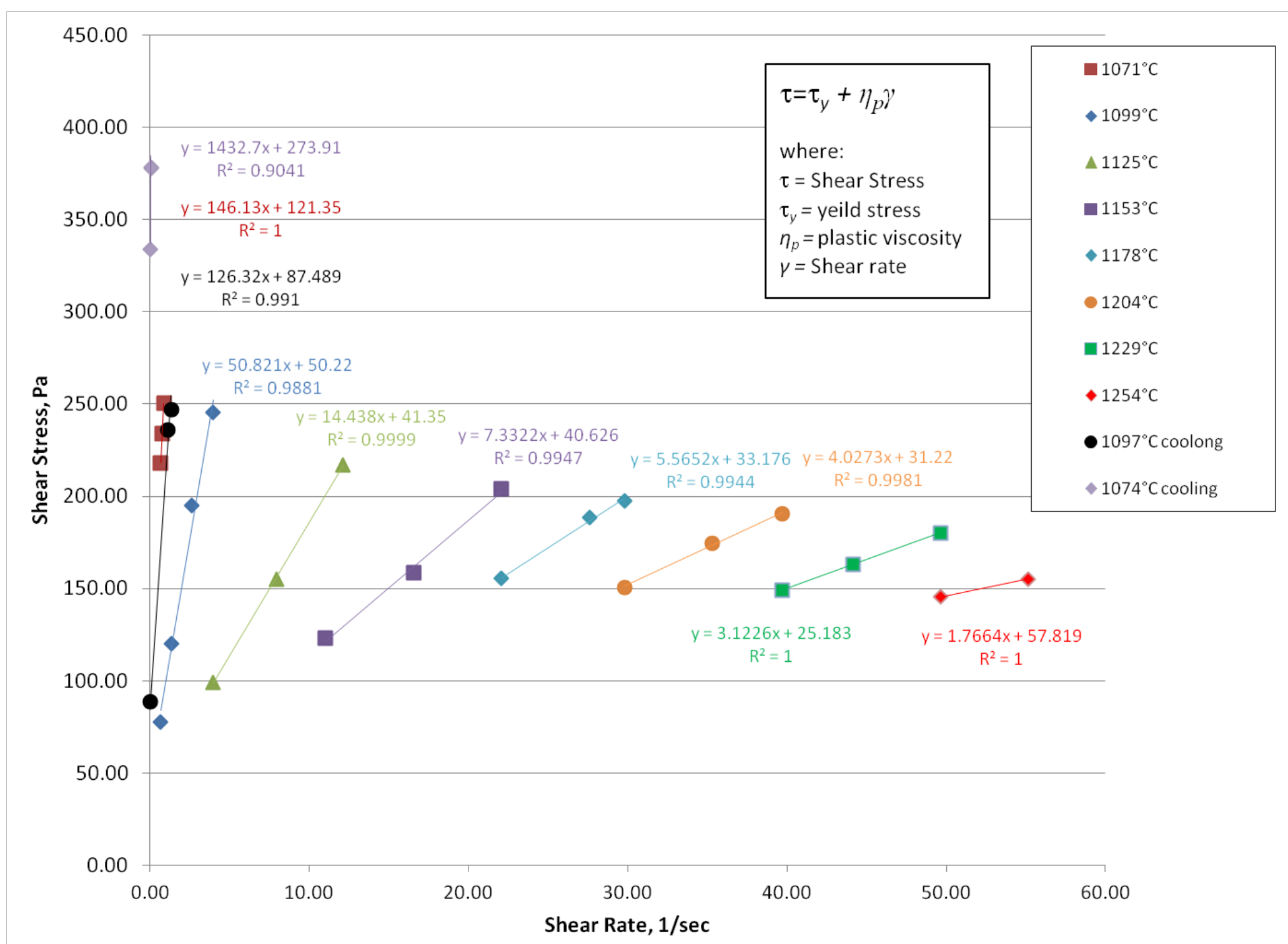

Figure 5. Shear stress versus shear rate of GC-Mo-Li-6.25 glass ceramic as a function of temperature. 


\subsubsection{Crystallinity}

Results of SEM and XRD analysis both show the targeted phases of oxyapatite, powellite, $\left(\mathrm{Zr}_{1-\mathrm{x}}, \mathrm{Ce}_{\mathrm{x}}\right) \mathrm{O}_{2}$, and noble metal oxides $\left[\left(\mathrm{Pd}_{y} \mathrm{Ru}_{x}, \mathrm{Rh}_{1-x-y}\right)_{1} \mathrm{O}_{2}\right]$ where formed at similar concentrations regardless of cooling rate. Figure 6 shows XRD patterns of GC-Mo-Li-6.25 at slow cooling rates from $0.25 \times$ up to $4 \times$ relative to the centerline cooling rate of a 2' diameter canister. The XRD scans were all very similar with only subtle differences in unit cell size. Powellite unit cell does vary slightly with cooling rate. Tungsten carbide is a contaminant (WC grinding chamber) present in the $4 \times$ XRD pattern from XRD sample preparation. Quantitative analysis of the XRD patterns was performed using TOPAS 4.2 software according to the fundamental parameters approach, with results given in Table 3 and graphically in Figure 6. The total crystallinity and concentrations of individual phases is somewhat variable but fairly constant as a function of cooling rate.

The only differences between cooling rates were observed in the SEM micrographs, which show slower cooling rates did result in larger crystal size (see Figure 7). Crystal size is commonly a function of time at temperature. The largest change in crystal size is between $1 \times$ and $0.75 \times$ slow cooling rates.

Image analysis was performed on the SEM backscattered electron (BSE) micrographs (150, 250, and $500 \times$ ) samples to confirm the quantitative XRD phase analysis results. The averaged image analysis results of the three images along with XRD results converted to volume $\%$ are given in Table 4 . Note that image analysis relies on differences in grey scale to distinguish different phases, making it difficult to separate crystalline phase with similar density. So the minor phases $\left(\mathrm{Zr}_{1-\mathrm{x}}, \mathrm{Ce}_{\mathrm{x}}\right) \mathrm{O}_{2},\left(\mathrm{Pd}_{y} \mathrm{Ru}_{x}, \mathrm{Rh}_{1-x-y}\right)_{1} \mathrm{O}_{2}$, and $\mathrm{Gd}_{3} \mathrm{BSi}_{2} \mathrm{O}_{10}$ were combined with the oxyapatite measured volume \% because they overlap in grey scale and could not be individually fit. The difference in grey scale between the glass and crystals were, however, adequate to confirm XRD results. The total crystallinity measured by both techniques was similar and confirm that there were no gross errors in either analysis.

Overall the XRD and SEM results show that crystalline phase formation in GC-Mo-Li-6.25 is not hindered by kinetics, so it should be quite accommodating to cooling rate differences from the center of a canister to the outside edges. Phase types and concentrations remain fairly constant as a function of slow cooling rate. 


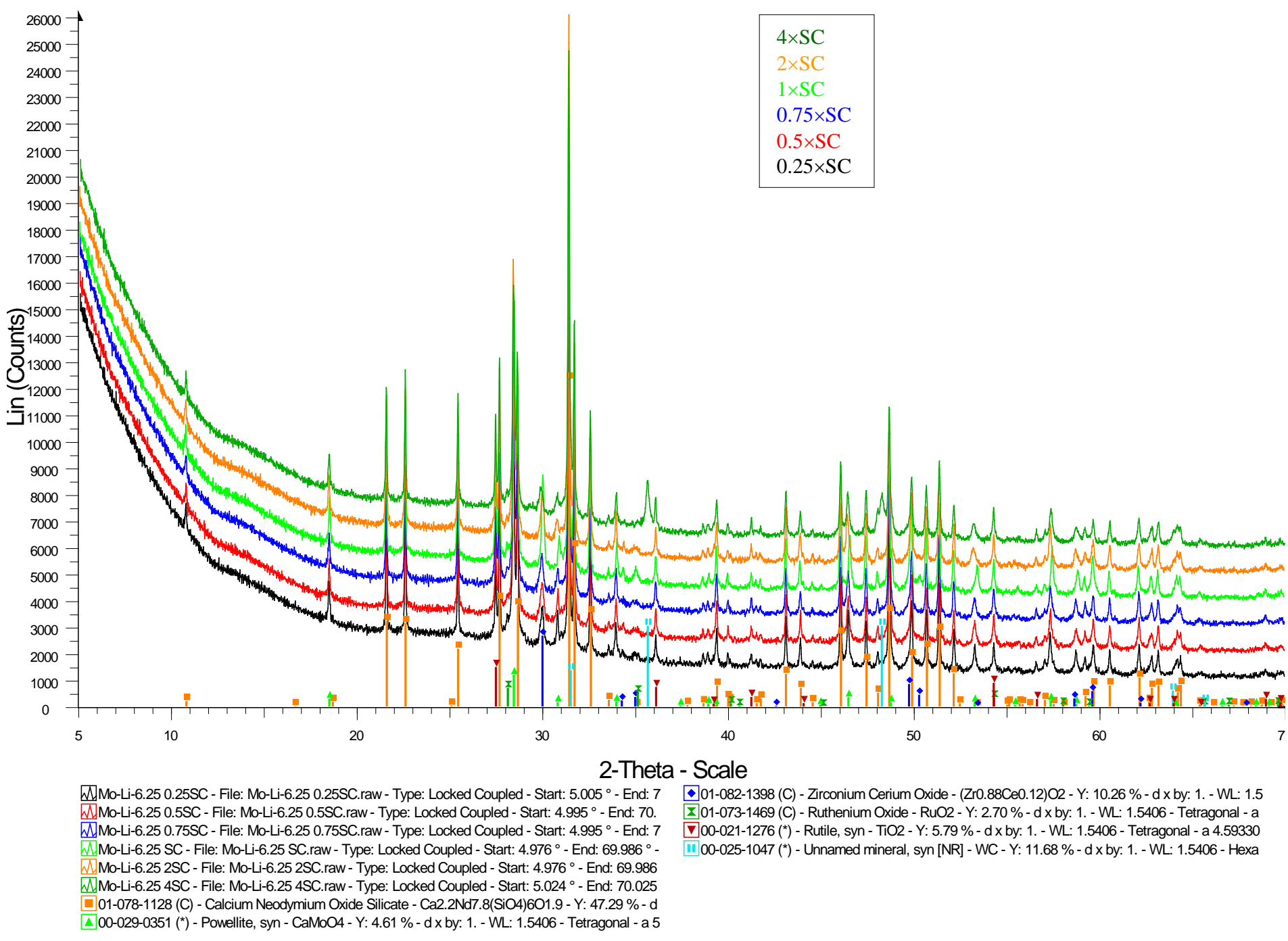

Figure 6. X-ray powder diffraction patterns of GC-Mo-Li-6.25 slow cooled at rates of $0.25 \times$ SC, $0.5 \times$ SC, $0.75 \times$ SC, $1 \times$ SC, $2 \times$ SC, and $4 \times$ SC relative to centerline cooling rate for 2' diameter canister ( $\mathrm{K}_{\alpha 2}$ fit and removed, amorphous background retained). 
Table 3. Quantitative XRD analysis results for GC-Mo-Li-6.25 glass ceramic as a function of slow cooling rate (relative to centerline cooling rate of 2' diameter canister).

\begin{tabular}{|c|c|c|c|c|c|c|c|}
\hline \multirow{2}{*}{$\begin{array}{l}\text { Slow } \\
\text { Cooling } \\
\text { Rate }\end{array}$} & \multicolumn{7}{|c|}{ Mass \% Measured by XRD } \\
\cline { 2 - 8 } & $\begin{array}{c}\text { Oxyapatite, } \\
\mathrm{Ca}_{2} \mathrm{Nd}_{8} \mathrm{Si}_{6} \mathrm{O}_{26}\end{array}$ & $\begin{array}{c}\text { Powellite, } \\
\mathrm{CaMoO}_{3}\end{array}$ & $\left(\mathrm{Zr}_{1-x}, \mathrm{Ce}_{\mathrm{x}}\right) \mathrm{O}_{2}$ & $\mathrm{Gd}_{3} \mathrm{BSi}_{2} \mathrm{O}_{10}$ & $\left(\mathrm{Pd}_{y} \mathrm{Ru}_{x}, \mathrm{Rh}_{1-x-y}\right)_{1} \mathrm{O}_{2}$ & Total Crystallinity & Amorphous \\
\hline $0.25 \times$ & 20.4 & 10.7 & 1.8 & 2.0 & 0.5 & 35.4 & 64.6 \\
\hline $0.5 \times$ & 21.3 & 10.8 & 2.2 & 2.0 & 0.5 & 36.9 & 63.1 \\
\hline $0.75 \times$ & 22.7 & 11.5 & 2.3 & 1.2 & 0.5 & 38.2 & 61.8 \\
\hline $1 \times$ & 20.6 & 9.9 & 3.5 & 1.5 & 0.4 & 35.9 & 64.1 \\
\hline $2 \times$ & 22.0 & 10.4 & 2.2 & 1.4 & 0.3 & 36.2 & 63.8 \\
\hline $4 \times$ & 19.3 & 9.4 & 1.5 & 1.8 & 0.2 & 32.1 & 67.9 \\
\hline
\end{tabular}

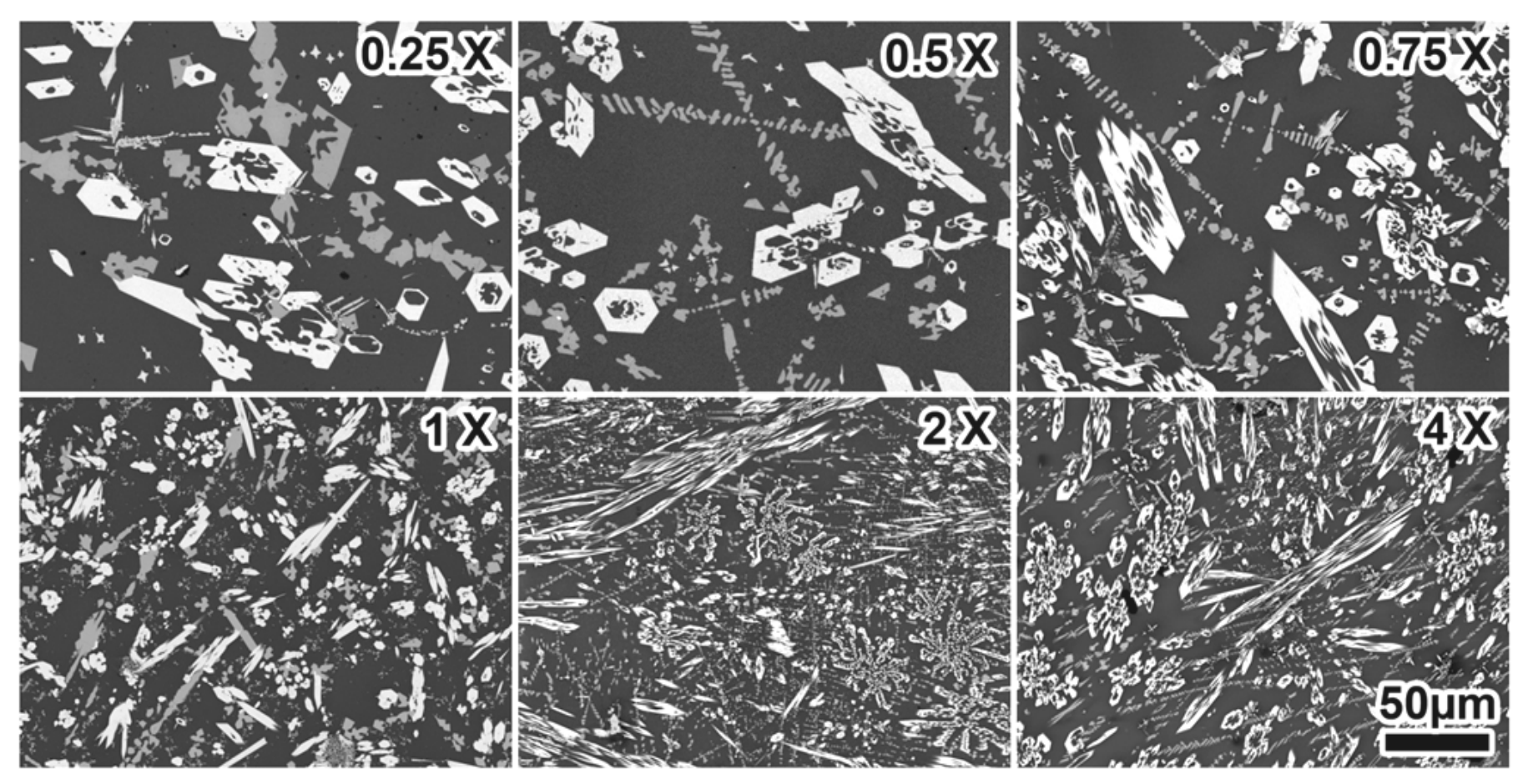

Figure 7. Backscattered electron images (500×) of GC-Mo-Li-6.25 slow cooled at various rates $(0.25 \times, 0.5 \times, 0.75 \times, 1 \times, 2 \times$, and $4 \times$ ) 
Table 4. Image analysis (SEM) and measured crystallinity (XRD) as a function of slow cool rate (values in volume \%).

\begin{tabular}{|c|l|c|c|c|c|c|c|c|}
\hline $\begin{array}{c}\text { Slow Cool } \\
\text { Rate }\end{array}$ & Technique & $\begin{array}{c}\text { Oxyapatite, } \\
\mathrm{Ca}_{2} \mathrm{Nd}_{8} \mathrm{Si}_{6} \mathrm{O}_{26}\end{array}$ & $\begin{array}{c}\text { Powellite, } \\
\mathrm{CaMoO}\end{array}$ & $\left(\mathrm{Zr}_{1-\times}, \mathrm{Ce}_{x}\right) \mathrm{O}_{2}$ & $\mathrm{Gd}_{3} \mathrm{BSi}_{2} \mathrm{O}_{10}$ & $\left(\mathrm{Pd}_{y} \mathrm{Ru}_{x}, \mathrm{Rh}_{1--x-y}\right)_{1} \mathrm{O}_{2}$ & Glass & Total \\
\hline $0.25 \times$ & SEM & 15.1 & 8.2 & NA & NA & NA & 76.6 & 100.0 \\
\hline $0.25 \times$ & XRD & 12.2 & 8.5 & 1.0 & 1.2 & 0.2 & 77.0 & 100.0 \\
\hline $0.5 \times$ & SEM & 14.6 & 7.8 & NA & NA & NA & 77.6 & 100.0 \\
\hline $0.5 \times$ & XRD & 12.8 & 8.7 & 1.2 & 1.2 & 0.2 & 75.9 & 100.0 \\
\hline $0.75 \times$ & SEM & 14.7 & 8.4 & NA & NA & NA & 76.9 & 100.0 \\
\hline $0.75 \times$ & XRD & 13.8 & 9.2 & 1.2 & 0.7 & 0.2 & 74.8 & 100.0 \\
\hline $1 \times$ & SEM & 15.3 & 9.2 & NA & NA & NA & 75.6 & 100.0 \\
\hline $1 \times$ & XRD & 12.3 & 7.9 & 1.9 & 0.9 & 0.2 & 76.8 & 100.0 \\
\hline $2 \times$ & SEM & 14.9 & 13.0 & NA & NA & NA & 72.1 & 100.0 \\
\hline $2 \times$ & XRD & 13.2 & 8.3 & 1.2 & 0.8 & 0.1 & 76.4 & 100.0 \\
\hline $4 \times$ & SEM & 12.2 & 12.5 & NA & NA & NA & 75.2 & 100.0 \\
\hline $4 \times$ & XRD & 11.3 & 7.3 & 0.8 & 1.0 & 0.1 & 79.5 & 100.0 \\
\hline
\end{tabular}

\section{Conclusions and Recommendations}

PNNL selected three glass ceramic compositions as candidates for possible melter testing in the INL CCIM. Electrical conductivity, viscosity, and crystallinity were measured as a function of temperature to down select to a single glass composition for the melter test.

Electrical conductivity was the first property measured, and values of preliminary glass ceramics immediately identified a processing concern. The first three glass ceramic compositions tested had significantly lower measured electrical conductivity than a typical borosilicate waste glass, eliminating them as selections for this melter test. Therefore, a new glass ceramic, GC-Mo-Li-6.25, was formulated with increased alkali (mainly in the form of $\mathrm{Li}$ ) to raise the conductivity of the glass ceramic closer to the typical conductivity range $(20-60 \mathrm{~S} / \mathrm{m})$ of borosilicate waste glasses. The measured electrical conductivity of the new formulation was deemed processable at $1300^{\circ} \mathrm{C}=14 \mathrm{~S} / \mathrm{m}$ (Table 5).

The viscosity results show that GC-Mo-Li-6.25 behaved similarly to a typical borosilicate glass melt at $1300^{\circ} \mathrm{C}$ down to $\sim 1100^{\circ} \mathrm{C}$, below which crystallization rapidly increased the viscosity as a function of temperature. Between $1100^{\circ} \mathrm{C}$ and $1070^{\circ} \mathrm{C}$, the viscosity increased by a factor of $3 \mathrm{from} \sim 100 \mathrm{~Pa} \cdot \mathrm{s}$ up to $\sim 300 \mathrm{~Pa} \cdot \mathrm{s}$. The ideal pouring range of 10 to $2 \mathrm{~Pa} \cdot \mathrm{s}$ equates to temperatures of 1150 to $1280^{\circ} \mathrm{C}$, respectively, however the melter should be operated at $\sim 1300-1350^{\circ} \mathrm{C}$ to maintain high electrical conductivity. The predicted viscosity at $1300^{\circ} \mathrm{C}$ is acceptable at $1.84 \mathrm{~Pa} \cdot \mathrm{s}$ (Table 5).

According to the viscosity results, formation and re-melting of crystals in these samples occurs in a matter of $\leq 10$ minutes. This indicates that the pour spout of the CCIM melter should operate similarly to borosilicate glass processing, with the possibility of a short delay when beginning the melt pour. Conversely, stopping pouring may be quicker than borosilicate glass with the rapid crystallization. The pour spout temperature may need to be raised to $\sim 1150^{\circ} \mathrm{C}$ to begin pouring. 
Table 5. Summary data table for GC-Mo-Li-6.25 glass ceramic.

\begin{tabular}{|l|c|c|c|}
\hline Property (validity range) & Predicted & \multicolumn{2}{|c|}{ Arrhenius Fit } \\
\hline & $T_{\mathrm{M}}=1300^{\circ} \mathrm{C}$ & Slope & Intercept \\
\hline Viscosity, $\eta\left(>1100^{\circ} \mathrm{C}\right)$ & $1.84 \mathrm{~Pa} \cdot \mathrm{s}$ & 26830 & -16.447 \\
\hline Electrical Conductivity, $\sigma\left(>750^{\circ} \mathrm{C}\right)$ & $14.11 \mathrm{~S} / \mathrm{m}$ & -10959 & 9.6137 \\
\hline \multicolumn{3}{|c|}{} \\
\hline Slow cool rate & $\begin{array}{c}\text { Crystallinity, } \\
\text { mass \% }\end{array}$ & $\begin{array}{c}\text { Crystallinity, } \\
\text { vol \% }\end{array}$ \\
\hline $0.25 \times$ & 35.4 & 33.0 \\
\hline $0.5 \times$ & 36.9 & 34.1 \\
\hline $0.75 \times$ & 38.2 & 35.2 \\
\hline $1 \times$ & 35.9 & 33.2 \\
\hline $2 \times$ & 36.2 & 33.6 \\
\hline $4 \times$ & 32.1 & 30.5 \\
\hline
\end{tabular}

Variations of the cooling rate from $4 \times$ to $0.25 \times$, relative to centerline cooling profile of a 2 -foot diameter canister, showed no differences in the phases formed and only minimal differences in there concentrations, see Table 5. The only significant differences observed were changes in crystal size as shown in Figure 7. These tests indicate that the glass ceramic should accommodate quite well the radial cooling rate differences present in a canister. The glass composition should also be consistent radially. The melter test should add more data points on the effect of cooling rate on crystallinity.

Based on the electrical conductivity and viscosity results, the recommended operating temperature of the melter should be initially maintained at $\sim 1300^{\circ} \mathrm{C}$ then adjusted based upon melt behavior observed in the melter test. Molybdenum is well above the solubility limit of the silicate melt and may phase separate in the melt at temperatures just below the melting temperature. A separate Mo-rich layer has not been observed in crucible melts, but it could possibly form in the melter. A series of cooling rates should be picked to optimize melter run operations; however, one canister should ideally be cooled at the standard cooling rate $(1 \times)$ and another large canister allowed to simply naturally cool outside a furnace to provide large range of cooling variability.

\section{References}

ASTM C 965-94. 1994. Standard Practice for Measuring Viscosity of Glass Above the Softening Point, American Society for Testing and Materials International, West Conshohocken, PA.

Caurant, D, O Majerus, E Fadel, and M Lenoir. 2007. "Effect of Molybdenum on the Structure and on the Crystallization of $\mathrm{SiO}_{2}-\mathrm{Na}_{2} \mathrm{O}-\mathrm{CaO}-\mathrm{B}_{2} \mathrm{O}_{3}$ Glasses." Journal of the American Ceramics Society 90(3):77483.

Cheary, RW, AA Coelho, and JP Cline. 2004. "Fundamental Parameters Line Profile Fitting in Laboratory Diffractometers." Journal of Research of the National Institute of Standards and Technology 109(1):1-25. 
Crum, JV, AL Billings, JB Lang, JC Marra, CP Rodriguez, JV Ryan, and JD Vienna. 2009. Baseline Glass Development for Combined Fission Products Waste Streams, Pacific Northwest National Laboratory, Richland, WA.

Crum, JV, TB Edwards, RL Russell, PJ Workman, MJ Schweiger, RF Schumacher, DE Smith, DK Peeler, and JD Vienna. 2012a. "DWPF Startup Frit Viscosity Measurement Round Robin Results." Journal of the American Ceramic Society. doi: 10.1111/j.1551-2916.2012.05220.x.

Crum, JV and J McCloy. 2012. High-Temperature Electrical Conductivity. GDL-Elec-Test-01 Rev. 0, Pacific Northwest National Laboratory, Richland, Washington.

Crum, JV, BJ Riley, LR Turo, M Tang, and A Kossoy. 2011. Summary Report: Glass-Ceramic Waste Forms for Combined Fission Products, Pacific Northwest National Laboratory, Richland, Washington.

Crum, JV, LA Turo, BJ Riley, M Tang, and A Kossoy. 2012b. "Multi-Phase Glass-Ceramics as a Waste Form for Comined Fission Products: Alkalis, Alkaline Earths, Lanthanides, and Transisition Metals." Journal of the American Ceramics Society 95(4):1297-303. 10.1111/j.1551-2916.2012.05089.x.

Crum, JV, LR Turo, BJ Riley, M Tang, A Kossoy, and KE Sickafus. 2010. Glass Ceramic Waste Forms for Combined CS+LN+TM Fission Products Waste Streams. FCRD-WAST-2010-000181, Pacific Northwest National Lab, Richland, Washington.

Hrma, PR and GF Piepel. 1994a. Property/composition relationships for Hanford high-level waste glasses melting at $1150^{\circ} \mathrm{C}$ volume 1: Chapters 1-11, Pacific Northwest National Laboratory, Richland, Washington.

Hrma, PR and GF Piepel. 1994b. Property/composition relationships for Hanford high-level waste glasses melting at $1150^{\circ} \mathrm{C}$ volume 2: Chapters 12-16 and appendices A-K, Pacific Northwest National Laboratory, Richland, Washington.

Riley, BJ, JV Crum, WC Buchmiller, BT Rieck, MJ Schweiger, and JD Vienna. 2009. Initial LaboratoryScale Melter Test Results for Combined Fission Product Waste. AFCI-WAST-PMO-MI-DV-2009000184, Pacific Northwest National Laboratory, Richland, Washington.

Ryan, JV, EC Buck, J Chun, JV Crum, BJ Riley, DM Strachan, SK Sundaram, LA Turo, and JV Vienna. 2009. Alternate Waste Forms: Aqueous Processing. AFCI-WAST-PMO-MI-DV-2009-000360, Pacific Northwest National Laboratory, Richland, Washington.

SRM-674b. 2007. X-ray Power Diffraction Intensity Set for Quantitative Analysis by X-Ray Diffraction, National Institute of Standards and Technology, Department of Commerce, Gaithersburg, MD. 